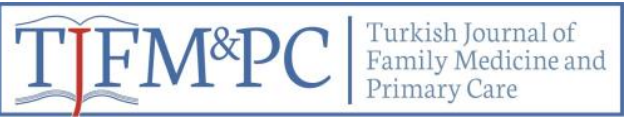

Original Article / Özgün Araştırma

\title{
Examination of the Relationship Among Depressive Symptom, Loneliness and Eating Attitudes in University Students with Sociodemographic Characteristics
}

\author{
Üniversite Öğrencilerinde Depresif Belirti, Yalnızlık ve Yeme Tutumu \\ Arasındaki İlişkinin Sosyodemografik Özelliklerle Birlikte İncelenmesi
}

\author{
Arzu Yıldırım ${ }^{*}$, Rabia Hacıhasanoğlu Aşılar ${ }^{2}$, Papatya Karakurt ${ }^{3}$, Cantürk Çapık ${ }^{4}$, Necla \\ Kasımoğlu ${ }^{5}$
}

ABSTRACT

Objective: This study was conducted to examine the relationship among depressive symptoms, loneliness and eating attitudes in university students together with sociodemographic characteristics. Method: This cross-sectional study was conducted with 2600 students from Erzincan University. Data were collected by a descriptive form, Beck Depression Inventory, The UCLA Loneliness Scale and Eating Attitudes Test-40. For data analysis,, Pearson's Correlation Analysis, Student t-test, Mann Whitney-U Test, Kruskall Wallis variance test and one way ANOVA were used besides percentages, minimum and maximum values, mean, standard deviations. Results: The mean UCLA Loneliness Scale score of all students was $39.3 \pm 9.5$. The prevalence was $32.8 \%$ for the depressive symptoms and $8.5 \%$ for the possible eating disorder. There was a very weak-positive relationship between the Beck Depression Inventory and UCLA Loneliness Scale, also there was a weak positive relationship between the Beck Depression Inventory and Eating Attitudes Test-40, average score ( $\mathrm{p}<0.05)$, On the other hand there was not a relationship between UCLA Loneliness Scale and Eating Attitudes Test-40 ( $>0.05)$. Gender was detected not to be effective on the risk of depressive symptoms and possible eating disorder scores. Males were more alone, females were underweight and normal weight, while males were overweight and obese. Conclusion: The present study has revealed that students experienced loneliness on a moderate level, the depressive symptom and possible eating disorder were widespread. It was also found that loneliness perception is a risk factor for depressive symptom and depressive symptom is a determinant factor for possible eating disorder. Health professionals should provide mental care to the students for depression, loneliness and eating disorders through, mental education, psychological counseling, and evidence-based guidance,and also they should develop effective strategies for good mental health literacy, for protection and improvement of mental health.

Key words: University students, depressive symptom, loneliness, eating attitude, health professionals

ÖZET

Amaç: $\mathrm{Bu}$ çalışma üniversite öğrencilerinde depresif belirti, yalnızlık ve yeme tutumu arasındaki ilişkinin sosyodemografik özelliklerle birlikte incelenmesi amacıyla yapılmıştır. Yöntem: Kesitsel türde olan bu çalışma Erzincan Üniversitesi’nde öğrenim gören 2600 öğrenci ile Nisan-Mayıs 2010 tarihleri arasında yürütülmüsstür. Veriler tanımlayıcı soru formu, Beck Depresyon Envanteri, UCLA Yalnızlık Ölçeği ve Yeme Tutumu Testi-40 ile toplanmıştır. Verilerin analizinde sayılar, yüzdelikler, en az ve en çok değerler ile ortalama ve standart sapmaların yanı sıra; Spearman korelasyon analizi, bağımsız gruplarda t-testi, Mann Whitney-U, Kruskall Wallis varyans ve tek yönlü varyans analizleri kullanılmıştır. Bulgular: Öğrencilerin UCLA Yalnızlık Ölçeği puan ortalaması $39,3 \pm 9,5$, depresif belirti yaygınlığı $\% 32,8$, olası yeme bozukluğu yaygınlığı ise $\% 8,5$ olarak belirlenmiştir. Beck Depresyon Envanteri ile UCLA-Yalnızlık Ölçeği arasında çok zayıf, Yeme Tutumu Testi-40 arasında zayıf düzeyde pozitif yönlü bir ilişki belirlenmiştir $(p<0,05)$. UCLA-Yalnızlık Ölçeği ile Yeme Tutumu Testi-40 arasında ise bir ilişki bulunmamıștır $(p>0,05)$. Ayrıca cinsiyetin depresif belirti riskini etkilemediği, istatistiksel olarak erkeklerin daha yalnız ve kızların olası yeme bozukluğu puan ortalamasının daha yüksek olduğu bulunmuştur. Sonuç: Bu çalışmada öğrencilerin orta düzeyde yalnızlık algıladığı, depresif belirti ve olası yeme bozukluğunun yaygın görüldüğü belirlenmiştir. Ayrıca yalnızlık algısının depresif belirtide, depresif belirtinin ise olası yeme bozukluğunda belirleyici olduğu görülmüştür. Sağlık profesyonelleri ruhsal eğitim, psikolojik danışmanlık ve kanıta dayalı rehberlik yolu ile öğrencilerde depresyon, yalnızlık ve yeme bozukluğu gibi sorunlara yönelik ruhsal bakım sağlamalı, iyi ruhsal sağlık okuryazarlığını ve ruhsal sağlığın korunması ve iyileştirilmesinde etkili stratejileri geliştirmelidir.

Anahtar kelimeler: Üniversite öğrencileri, depresif belirti, yalnızlık, yeme tutumu, sağlık profesyonelleri

Received Date / Geliş tarihi: 24.04.2018, Accepted Date / Kabul tarihi: 11.07.2018

${ }^{1}$ Erzincan Binali Yıldırım Üniversitesi Sağlık Bilimleri Fakültesi, Ruh Sağlığı ve Psikiyatri Hemşireliği ABD, Erzincan, TÜRKIYYE

${ }^{2}$ Erzincan Binali Yıldırım Üniversitesi Sağlık Bilimleri Fakültesi, Halk Sağlı̆̆ı Hemşireliği ABD, Erzincan, TÜRKIYYE

${ }^{3}$ Erzincan Binali Yıldırım Üniversitesi Sağlık Bilimleri Fakültesi, Hemşirelik Esasları ABD, Erzincan, TÜRKIYE

${ }^{4}$ Atatürk Üniversitesi Hemşirelik Fakültesi, Halk Sağlığı Hemşireliği ABD, Erzurum, TÜRKIYE

${ }^{5}$ Erzincan Binali Yıldırım Üniversitesi Sağlık Bilimleri Fakültesi, Çocuk Sağlığı ve Hastalıkları Hemşireliği, Erzincan, TÜRKIYE

*Address for Correspondence / Yazışma Adresi: Arzu Yıldırım, Erzincan Binali Yıldırım Üniversitesi Sağlık Bilimleri Fakültesi/Ruh Sağlı̆̆ı ve Psikiyatri Hemşireliği ABD, Erzincan, TÜRKIYE. E-mail: yildirimarzu25@hotmail.com

Yıldırım A, Aşılar RH, Karakurt P, Çapık C, Kasımoğlu N. Üniversite Öğrencilerinde Depresyon, Yalnızlık, Yeme Bozukluğu Yaygınlığı ve İlişkili Etkenlerin Belirlenmesi. TJFMPC, 2018;12(4):264-274. DOI: 10.21763/tjfmpc.462906 


\section{GíRiş}

Bedensel, ruhsal ve toplumsal yönden birçok değişimin iç içe yaşandığı, birey ve çevresi için çalkantılı ve sıkıntılı, erişkin yaşama geçiş dönemi olan ergenlikte ${ }^{1}$ ve genç bireylerde sağlığın korunması ve geliştirilmesi öncelikli ve önemlidir. Üniversite öğrencilerinin büyük çoğunluğu ilk defa kendi başlarına yaşamaya başlamakta $^{2}$ ve aileden ayrılma, yeni çevre ve arkadaş edinme, yalnız kalma korkusu, arkadaş ilişkilerindeki ve okul başarısındaki yetersizlikler, ekonomik güçlükler, yurt hayatına alışma, gelecekteki mesleği ve çalışma hayatı ile ilgili anksiyete gibi birçok sorunla karşı karşıya kalabilmektedir. Karşılaşılabilen bu toplumsal, kültürel, ekonomik zorlanma etkenleri ve yaşam tarzı değişiklikleri nedeni ile gençler depresyon, anksiyete, yalnızlık ve yeme bozukluğu gibi ruhsal sorunlar yaşayabilmektedir. ${ }^{3}$

Erken başlangıçlı depresyon yaygın, yinelemeleri olan ve özkıyım riski taşıyan bir bozukluktur. Ergenlerde depresyonun en ağır sonucu özkıyımdır. Depresyonda nokta yaygınlık ergenlerde \%3-8 ve ergenliğin sonunda yaşam boyu yaygınlık \%20 olarak bildirilmektedir. ${ }^{4}$ Gençlerde depresyon ruhsal, toplumsal ve akademik işlevlerde ciddi düzeyde bozulmalara yol açmakta ve gelişimsel sorunların aşılmasını engellemektedir. ${ }^{5,6}$ Suudi Arabistan'da yapılan bir çalışmada ${ }^{7}$ üniversite öğrencilerinin \%21.9'unda depresyon, \%9,9'unda major depresyon belirtileri ve \%1,1'inde özkı1m düşüncesi; İran'da tıp öğrencileri ile yapılan diğer bir çalışmada öğrencilerin \%50'sinde depresif belirti olduğu tespit edilmiştir. ${ }^{8}$ Ülkemizde yapılan bir çalışmada ${ }^{9}$ da öğrencilerin \%35,2'sinde depresif belirti görüldüğü, 6386 öğrenci ile Genel Sağlık Anketi (GSA-12) kullanılarak yapılan başka bir çalışmada ise öğrencilerin \%20.4'ünde fiziksel ve ruhsal sağlıkta bozulma olduğu bildirilmiştir. ${ }^{10}$

Yalnızlık hızlı sosyal değişimin ve karmaşanın yaşandığı dönemlerde artış göstermektedir. Yaşam boyunca bireylerin kendilerini en fazla yalnız hissettikleri dönemler ergenlik ve genç erişkinliktir. $\mathrm{Bu}$ dönemlerde kimlik kazanma ve kendini gerçekleştirme çabaları yoğun olduğundan genç, yalnız kalmaktan kaçınır. Peplau'ya göre yalnızlık, bireyin sosyal çevresiyle iletişiminin hem niteliksel hem de niceliksel bozulması durumunda yaşanan hoş olmayan bir duygudur. Bu duygu bireyin fizyolojik, ruhsal, toplumsal ve kültürel yapısı ile ilgilidir. ${ }^{11}$
Türkiye'de bir üniversite psikolojik danışma merkezine başvuran 550 öğrenci ile yapılan bir çalışmada öğrencilerin orta düzeyde yalnızlık yaşadığı, \%56,2'sinin ciddi düzeyde depresif belirti gösterdiği ve yalnızlık ile depresif belirti arasında orta düzeyde bir ilişki olduğ ${ }^{12}$, yurt dışında yapılan bir çalışmada ise arkadaş ve akrabasının olmadığını belirten öğrencilerin depresyon düzeyinin önemli olarak yüksek olduğu belirlenmiştir. ${ }^{8}$

Yeme bozuklukları yüksek düzeyde yaygınlığı ve olası ciddi fiziksel ve ruhsal sonuçlarından dolayı ergenlerde görülen önemli bir toplum sağlığı sorunudur. ${ }^{13}$ Beden ağırlığ 1 ile aşırı uğraş ve yeme davranışlarındaki değişikliklerle giden anoreksiya nervoza, bulimiya nervoza ve tıkanırcasına yeme bozukluğu gibi bozuklukları içerir. Amerika'da yapılan toplum temelli bir çalışmada yaşam boyu yaygınlığ kadınlarda \%0,9-\%3,5, erkeklerde ise \%0,3\%2 olarak bulunmuştur. ${ }^{4}$ Ülkemizde 2907 ergen ile yapılan bir çalışmada ise yeme bozukluğu nokta yaygnlığı \%2,3, k1zlarda $\%$ olarak bildirilmiştir. ${ }^{14}$ Yeme bozukluklarının DSM-5 (Amerikan Psikiyatri Birliği, 2013) $)^{15}$ tanı ölçütlerinde yapılan değişiklikler ile bu yaygınlı oranları yükselmektedir. ${ }^{4}$ Yeme bozukluğu bireyin yalnızca iyilik haline değil, aynı zamanda fiziksel sağlığına da zarar vermekte ve ölümcül sonuçlara yol açabilmektedir., ${ }^{46}$

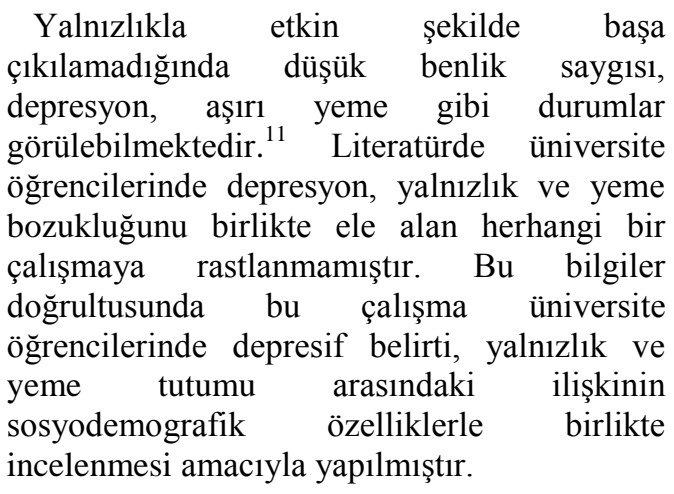

\section{YÖNTEM}

\section{Örneklem}

Kesitsel türde olan bu çalışmanın evrenini 2009-2010 eğitim-öğretim y1lı bahar yarıyılında Erzincan Üniversitesi'nde il merkezinde bulunan Eğitim Fakültesi (s=2848, $\% 40)$, Fen-Edebiyat Fakültesi (s=563, \%68), Hukuk Fakültesi $(\mathrm{s}=435, \% 35,6)$, İktisadi ve İdari Bilimler Fakültesi (s=298, \%22,2), Sağlık Yüksekokulu $\quad(\mathrm{s}=242, \quad \% 86,4), \quad$ Meslek 
Yüksekokulu $\quad(s=2167, \quad \% 21,6), \quad$ Sağlık Hizmetleri Meslek Yüksekokulu (s=147, $\% 78,2)$ ve Turizm ve Otelcilik Meslek Yüksekokulu'nda $(\mathrm{s}=157, \% 40,8)$ öğrenim gören toplam 6857 öğrenci oluşturmuştur. Çalışmada herhangi bir örneklem seçimine gidilmemiş olup, Nisan-Mayıs 2010 tarihlerinde fakülte/yüksekokul/meslek yüksekokulunda öğrenim gören bütün öğrencilere ulaşılması hedeflenmiştir. Ancak belirtilen tarihlerde devamsızlık ve çalışmaya katılmaya onay vermeme nedeniyle 2600 öğrenciye ulaşılmış (evrenin \%37,9'u) ve 143 öğrenci anket formlarını eksik doldurduğu için çalışma dışı bırakılmıştır.

\section{Kullanılan Araçlar}

Tanımlayıcı Soru Formu: Öğrencilerin yaşı, cinsiyeti, fakülte/yüksekokul/meslek yüksekokulu, sınıfı, Beden Kitle İndeksi (BKİ) ve sigara içme durumunu belirleyen altı sorudan oluşmaktadır.

Tanımlayıcı soru formunda öğrencilere boy ve kiloları sorulmuş ve BKI buna göre belirlenmiştir. Dünya Sağlık Örgütü (DSÖ) standartları esas alınarak BKİ, vücut ağırlığı $(\mathrm{kg}) \quad /$ boy uzunluğu $(\mathrm{m})^{2}$ olarak hesaplanmıştır. Buna göre $\mathrm{BK} \dot{\mathrm{I}}<18,5$ zayıf, 18,5-24,9 arasi normal, 25-29,9 fazla kilolu, $30-39,9$ aras 1 obez ve $\geq 40$ morbid obez olarak sınıflandırılmıştır. ${ }^{17}$

Beck Depresyon Envanteri (BDE): Depresyon yönünden riski belirlemekte ve depresif belirtilerin düzeyini ve şiddet değişimini ölçmektedir. Özgün formu Beck ${ }^{18}$ (1961) tarafından geliştirilmiş ve Hisli (1989) tarafından Türkçe'ye uyarlanmıștır. ${ }^{19}$ Toplam 21 kendini değerlendirme cümlesi içermekte ve dörtlü likert tipi ölçüm sağlamaktadır. Her madde 0-3 arasında puan almakta ve toplam puan 0-63 arasında değişmektedir. Toplam puanın yüksek oluşu depresyon düzeyi ya da şiddetinin yüksek oluşunu göstermektedir. Ölçeğin geçerlik ve güvenirlik çalışmasında kesme puanı 17, iç tutarlılık katsayısı 0,80 olarak belirlenmiş olup ${ }^{19,20}$ bu çalışmada Cronbach alfa katsayısı 0,88 olarak hesaplanmıştır.

UCLA Yalnızlık Ölçeği (UCLA-YÖ): Birey tarafindan algılanan yalnızlığın derecesini belirlemek amaciyla Russell ve arkadaşları tarafından 1980 yılında geliştirilmiştir. ${ }^{21}$ Türkçe geçerlilik ve güvenirliği Demir ${ }^{22}$ tarafindan (1989) yapılmış olan ölçek, 20 maddeyi içermektedir. İfadelerin 10 'u düz, 10 'u ters olarak kodlanmakta ve dörtlü likert tipi derecelendirilmektedir. Ölçekten alınabilecek puan aralığı 20-80 olup, puan arttıkça yalnızlık düzeyi artmaktadır. Ölçeğin Cronbach alfa katsayısı 0,96 olarak bulunmuş olup $^{22} ;$ bu araştırmada 0,94 olarak belirlenmiştir.

Yeme Tutumu Testi (YTT-40): Anorektik hastaların yemek yemekle ilgili davranış ve tutumlarını, normal bireylerde ise var olan yeme davranışlarındaki olası bozuklukları ölçmektedir. Garner ve Garfinkel ${ }^{23}$ (1979) tarafindan geliştirilmiş, Erol ve Savaşır ${ }^{24}$ (1989) tarafından Türkçe'ye uyarlanmıştır. Likert tipi altı basamaklı olup, 40 maddeden oluşmaktadır. Maddelerden 1, 18, 19, 23, 27 ve 39 için "bazen" 1 puan, "nadiren" 2 puan, "hiçbir zaman" 3 puan ve "diğer seçenekler" 0 puan olarak değerlendirilir. Ölçeğin diğer maddeleri için "daima" 3 puan, "çok sık" 2 puan, "sık sık" 1 puan ve "diğer seçenekler" 0 puan olarak değerlendirilir. Alınan puanlar toplanarak toplam puan elde edilir. Ölçeğin yeme bozukluğu açısından klinik değerlendirmeyi gerektirecek kesme puanı 30 olarak belirlenmiştir. Yapılan güvenirlik analizi sonucu Cronbach alfa katsayısı 0,70 olarak hesaplanmış ${ }^{20,25}$, bu çalışmada ise 0,72 olarak tespit edilmiştir.

\section{Verilerin Toplanması}

Araştırmada kullanılan formlar belirtilen tarihlerde araştırmacılar tarafindan ders saatinde dağıtılmış ve toplanmıştır. Öğrenciler tarafindan formların doldurulması ortalama 2025 dakikada tamamlanmıştır.

\section{İstatistiksel Analiz}

Verilerin değerlendirilmesinde SPSS for Windows 17 paket programı kullanılmış ve $\mathrm{p}<0.05$ anlamlılık düzeyi olarak kabul edilmiştir. Verilerin analizinde sayılar, yüzdelikler, en az ve en çok değerler ile ortalama ve standart sapmaların yanı sıra; ölçekler arasındaki ilişkiyi belirlemek için, veriler normal dağılıma uygunluk göstermediğinden Spearman korelasyon analizi, çalışma değişkenlerine göre BDE, UCLA-YÖ ve YTT-40 puanları arasında anlamlı farklılık olup olmadığını belirlemek için bağımsız gruplarda t-testi, Mann WhitneyU, Kruskall Wallis varyans ve tek yönlü varyans analizleri kullanılmıştır. Tek yönlü varyans analizi sonucunda farkın hangi gruplardan kaynaklandığını belirlemek için varyansların homojen olduğu gruplarda Scheffe, homojen olmadiğı gruplarda Dunnet'C testleri kullanılmıştır. Varyansların 
homojenlik durumları ise Levene testi ile belirlenmiştir.

\section{Etik İlkeler}

Araştırmanın yapılabilmesi için Erzincan Üniversitesi Rektörlüğü'nden yazılı izin (24/03/2010 tarih ve 1684 sayılı) alınmıştır. Araştırma kapsamına alınan öğrencilere araştırmanın amacı, planı ve yararları açıklanıp, araştırmadan istedikleri zaman ayrılabilecekleri ifade edilmiş ve sözlü izinleri alınarak gönüllü olanlar çalışmaya dahil edilmiştir.

\section{BULGULAR}

Öğrencilerin \%53,6'sının k1z olduğu, \%43,8'inin eğitim fakültesinde, \%45,3'ünün 1.sınıfta öğrenim gördüğü, \%78,4'ünün sigara içmediği ve \%77'sinin normal kiloda olduğu belirlenmiştir (Tablo 1). Öğrencilerin yaşları 17-39 arasında değişmekte olup, yaş ortalaması $20,9 \pm 2,0$ y1l, BKİ ortalamas1 ise $21,7 \pm 2,9$ olarak bulunmuştur.

Çalışmada BDE puan ortalaması 13,6 $\pm 9,7$, UCLA-YÖ 39,3 $\pm 9,5$ ve YTT-40 puan ortalaması 16,9 $\pm 9,4$ olarak belirlenmiștir (Tablo 2). Depresif belirti yaygınlığ $\geq 17) \% 32,8 \quad(\mathrm{~s}=853)$, olası yeme bozukluğu yaygınlığ1 (YTT-40 $\geq 30)$ ise $\% 8,5 \quad(\mathrm{~s}=220)$ olarak saptanmıştır.

Tablo 1. Öğrencilerin sosyodemografik özelliklerinin dağılımı (s=2600)

\begin{tabular}{|c|c|c|}
\hline & Sayı & Yüzde \\
\hline \multicolumn{3}{|l|}{ Cinsiyet } \\
\hline $\mathrm{K} 1 \mathrm{z}$ & 1393 & 53,6 \\
\hline Erkek & 1207 & 46,4 \\
\hline \multicolumn{3}{|l|}{ Fakülte/Yüksekokul/Meslek Yüksekokulu } \\
\hline Eğitim Fakültesi & 1140 & 43,8 \\
\hline Fen Edebiyat Fakültesi & 383 & 14,7 \\
\hline Hukuk Fakültesi & 155 & 6,0 \\
\hline İktisadi ve İdari Bilimler Fakültesi & 66 & 2,5 \\
\hline Sağlık Yüksekokulu & 209 & 8,0 \\
\hline Meslek Yüksekokulu & 468 & 18,0 \\
\hline Sağlık Hizmetleri Meslek Yüksekokulu & 115 & 4,4 \\
\hline Turizm ve Otelcilik Meslek Yüksekokulu & 64 & 2,6 \\
\hline \multicolumn{3}{|l|}{ Sinif } \\
\hline 1. & 1177 & 45,3 \\
\hline 2. & 561 & 21,6 \\
\hline 3. & 441 & 17,0 \\
\hline 4. & 421 & 16,1 \\
\hline \multicolumn{3}{|l|}{ Sigara içme durumu } \\
\hline İçiyor & 451 & 17,3 \\
\hline İçmiyor & 2037 & 78,4 \\
\hline Bırakmış & 112 & 4,3 \\
\hline \multicolumn{3}{|l|}{ BKI* } \\
\hline Zayıf $(<18,5)$ & 281 & 10,8 \\
\hline Normal $(18,5-24,9)$ & 2002 & 77,0 \\
\hline Fazla kilolu $(25-29,9)$ & 286 & 11,0 \\
\hline Obez $(30-39,9)$ & 31 & 1,2 \\
\hline
\end{tabular}

Tablo 2. Öğrencilerin BDE, UCLA-YÖ ve YTT-40 puan ortalamalarının dağılımı

\begin{tabular}{|ll|l|l|l|}
\hline & Ölçekler & Ort \pm SS & $\begin{array}{l}\text { Alınabilecek } \\
\text { puan aralığ }\end{array}$ & Alınan puan aralığ \\
\hline & BDE & $13,6 \pm 9,7$ & $0-63$ & $0-62$ \\
\hline \multirow{2}{*}{ YÖ } & UCLA- & $39,3 \pm 9,5$ & $20-80$ & $20-73$ \\
& & $16,9 \pm 9,3$ & $0-120$ & $1-105$ \\
\hline
\end{tabular}

BDE: Beck Depresyon Envanteri, UCLA-YÖ: UCLA Yalnızlık Ölçeği, YTT-40 Yeme Tutumu Testi-40, Ort.: Ortalama, SS: Standart sapma 


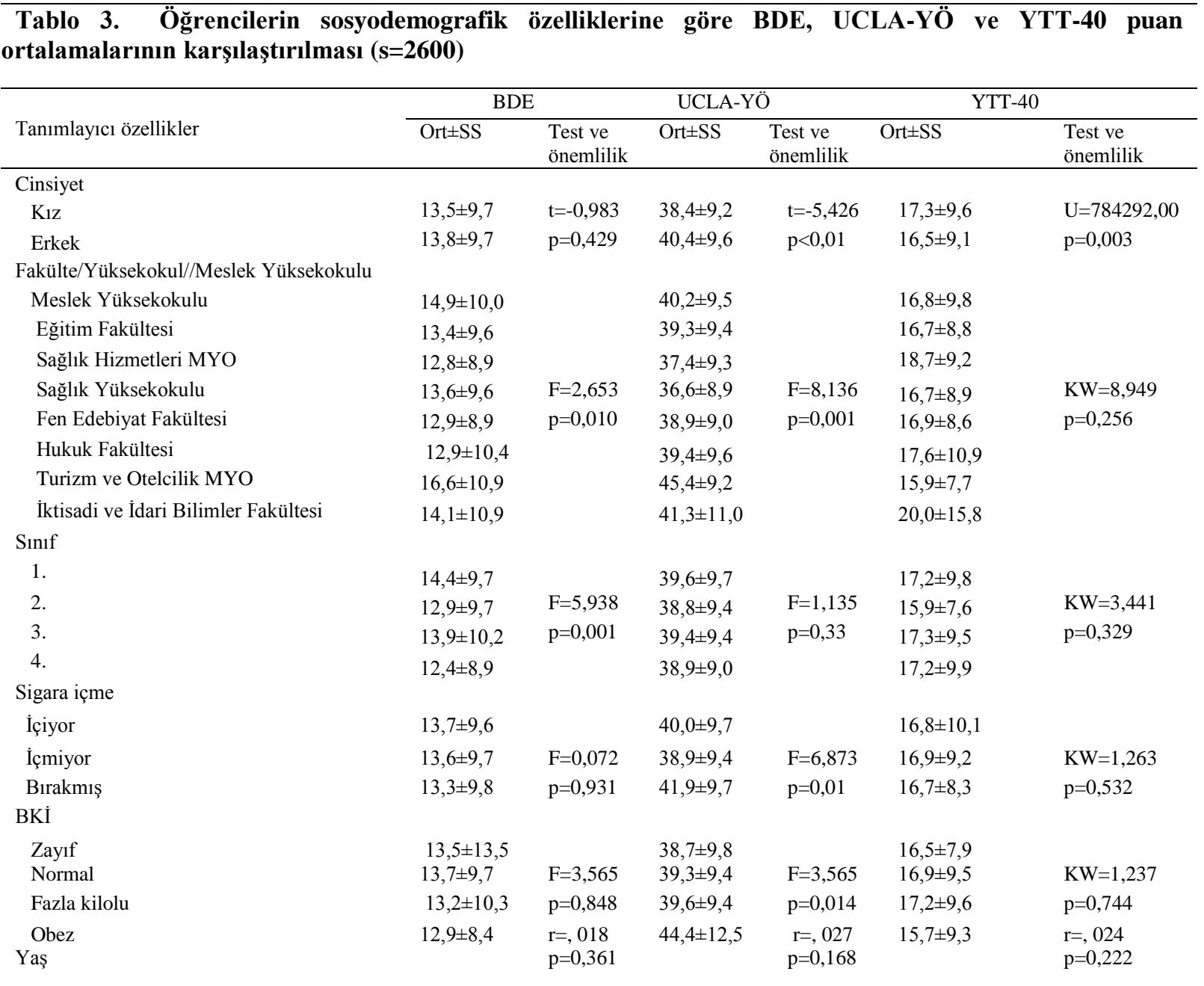

BDE: Beck Depresyon Envanteri, UCLA-YÖ: UCLA Yalnızlık Ölçeği, YTT-40 Yeme Tutumu Testi-40,

Ort.: Ortalama, SS: Standart sapma; t: Bağımsız gruplarda t-testi; U: Mann Whitney-U testi; KW: Kruskall Wallis varyans analizi; F: Tek yönlü varyans analizi

\section{Tablo 4. Öğrencilerin BDE, UCLA-YÖ ve YTT-40 puan ortalamaları arasındaki ilişki}

\begin{tabular}{lccc}
\hline Ölçekler & $\begin{array}{c}\text { UCLA-YÖ } \\
{ }^{*}\end{array}$ & $\begin{array}{c}\text { BDE } \\
{ }^{*}\end{array}$ & $\begin{array}{c}\text { YTT-40 } \\
\text { r }^{*}\end{array}$ \\
\hline UCLA-YÖ & 1,00 & $0,071^{* * *}$ & $-0,004$ \\
BDE & $0,071^{* *}$ & 1.00 & $0,205^{*}$ \\
YTT-40 & $-0,004$ & $0,205^{*}$ & 1,00 \\
\hline
\end{tabular}

Spearman korelasyon analizi*, ${ }^{* *} \mathrm{p}<0.05$, BDE: Beck Depresyon Envanteri, UCLA-YÖ: UCLA Yalnılılk Ölçeği, YTT-40: Yeme Tutumu Testi.

Araştırmaya katılan öğrencilerin cinsiyeti ile BDE puan ortalaması arasında anlamlı bir

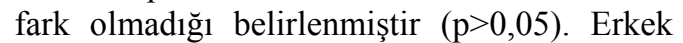
öğrencilerin UCLA-YÖ puan ortalamasının kızlara göre, kızların YTT-40 puan ortalamasının ise erkeklere göre anlamlı düzeyde yüksek olduğu bulunmuştur ( $p<0,01)$.

Öğrencilerin öğrenim gördükleri fakülte/yüksekokul/meslek yüksekokula göre BDE puan ortalamaları arasındaki fark istatistiksel olarak anlamlı bulunmasina rağmen ( $\mathrm{p}<0,01)$, yapılan ileri analizde (Tukey ileri analizi) farkın anlamlı olmadığı, tüm bölümlerin benzer puan ortalamalarına sahip oldukları belirlenmiştir. Öğrencilerin fakülte/yüksekokul/meslek yüksekokula göre UCLA-YÖ puan ortalaması istatistiksel olarak anlamlı bulunmuştur $(\mathrm{p}<0,01)$. Yapılan ileri analizde Turizm ve Otelcilik Yüksekokulu ile İktisadi ve İdari Bilimler Fakültesi öğrencilerinin yalnızlı puanının diğer bölümlerden daha fazla olduğu, Sağlık Yük- 
sekokulu öğrencilerinin yalnızlık puanının ise Meslek Yüksekokulu, Eğitim Fakültesi ve Turizm ve Otelcilik Meslek Yüksekokulundan daha düşük olduğu belirlenmiştir. Fakülte/yüksekokul ile YTT-40 puan ortalaması arasında ise anlamlı düzeyde fark olmadığ 1 tespit edilmiştir ( $\mathrm{p}>0,05)$.

Öğrencilerin sınıf düzeyi ile BDE puan ortalaması arasında istatistiksel olarak anlamlı fark olduğu görülmüştür $(p<0,01)$. Birinci sınıf öğrencilerinin en yüksek BDE puan ortalamasına sahip olduğu ve yapilan ileri analizde 1. sinifların hem 2. siniflar, hem de 4. sınıflar ile fark oluşturduğu belirlenmiştir. Sınıf düzeyi ile UCLA-YÖ ve YTT-40 puan ortalaması arasında ise anlamlı bir fark olmadığı saptanmıştır $(\mathrm{p}>0,05)$.

Sigara içme durumu ile BDE ve YTT-40 puan ortalaması arasında anlamlı bir fark olmadiğ 1 belirlenmiştir $(p>0,05)$. Sigara içen öğrencilerin UCLA-YÖ puan ortalamasının sigara içmeyenlere göre anlamlı düzeyde yüksek olduğu tespit edilmiştir $(p<0,05)$.

Araştırmada öğrencilerin BKİ düzeyine göre BDE ve YTT-40 puan farklarının istatistiksel olarak anlamlı olmadığı $(p>0,05)$, UCLA-YÖ puan ortalaması farkının ise anlamlı olduğu saptanmıştır $(p<0,05)$. Yapılan ileri analizde obezlerin UCLA-YÖ puan ortalamasının zayıf, normal ve fazla kilolulardan daha yüksek olduğu belirlenmiştir.

Öğrencilerin yaşı ile BDE, UCLA-YÖ ve YTT-40 puan ortalamaları arasında anlamlı bir ilişki olmadığı tespit edilmiştir $(\mathrm{p}>0,05)$ (Tablo 3).

Yapilan Spearman korelasyon analizine göre BDE ile UCLA-YÖ arasında çok zayıf, YTT-40 arasında zayıf düzeyde pozitif yönlü anlamlı bir ilişki belirlenmiştir ( $\mathrm{p}<0,05)$. Aynı analizde UCLA-YÖ ile YTT40 arasında ise anlamlı bir ilişki bulunmamıştır $(\mathrm{p}>0,05)$ (Tablo 4)

\section{TARTIŞMA}

Üniversite öğrencilerinin ruhsal sağlığının koruması ve geliştirilmesi öğrencilerin akademik başarısını artırır ve gelişimlerini destekler. $\mathrm{Bu}$ nedenle öğrencilerde yaygın görülebilen depresyon, yalnızlık ve yeme bozukluğu gibi ruhsal sorunların erken dönemde tespiti ve tedavisi büyük önem arz etmektedir. Üniversite öğrencilerinde depresif belirti, yalnızlık ve yeme tutumu arasındaki ilişkinin sosyodemografik özelliklerle birlikte incelenmesi amacıyla yapılan bu araştırmada bulgular literatür ışığında tartışılmıştır.

$\mathrm{Bu}$ araştırmada öğrencilerin BDE puan ortalamasının $(13,6 \pm 9,7)$ ölçekten alınabilecek en düşük ve en yüksek puanlara göre düşük düzeyde olduğu bulunmuş ve depresif belirti yaygınlığının ise \%32,8 olduğu belirlenmiştir. Suudi Arabistan'da Hasta Sağlık Soru Formu (PHQ) kullanılarak 1696 lisans öğrencisi ile yapılan bir çalışmada öğrencilerin \%21,9’unda depresyon, \%9,9'unda major depresyon ${ }^{7}$; Bat1 Nijerya'da Epidemiyolojik Çalışma Merkezleri Depresyon Ölçeği (CES-D)'ne göre ögrrencilerin $\% 7$ 'sinde ciddi, \%25,2'sinde ortaciddi düzeyde depresyon ${ }^{26}$; Hindistan'da BDE kullanılarak yapılan çalışmada ${ }^{27}$ tıp ögrencilerinin \%51,3'ünde ve Malezya'da tıp fakültesi k1z öğrencilerinin \%65,5'inde depresyon riski olduğu bildirilmektedir. ${ }^{16}$ Ülkemizde 1971 üniversite öğrencisi ile yapılan bir çalışmada ${ }^{9}$ da depresif belirti yaygınlığının \%35,2 olduğu, diğer çalışmalarda ise sırası ile $\% 18,3$ ve $\% 25$ olduğu rapor edilmektedir. ${ }^{28,29}$ Ayrıca bir çalışmada BDE puan ortalamasının bu çalışma sonucuna göre düşük ${ }^{9}$, bir çalışmada benzer ${ }^{28}$ ve diğer bir çalışmada ise yüksek olduğu belirlenmiştir. $^{12^{3}}$

Öğrencilerin UCLA-YÖ puan ortalamasının 39,3 $\pm 9,5$ olduğu saptanmıştır. Ölçekten alınabilecek en düşük ve en yüksek puanlar dikkate alındığında, öğrencilerin orta düzeyde yalnızlık algıladığı söylenebilir. Ülkemizde üniversite öğrencileri ile yapılan çalışmalarda UCLA-YÖ puan ortalamasının bu çalışma sonucu ile karşılaştırıldığında düşük ${ }^{12,30,31}$ veya yüksek olduğu görülmüștür. ${ }^{32,33}$ Norveçte 18 34 yaş aralığında 12000 üniversite öğrencisi ile Toplumsal ve Duygusal Yalnızlık Ölçeği kullanılarak yapılan bir çalışmada ise öğrencilerin \%8,4'ü toplumsal, \%9,1'i duygusal yalnızlık yaşadığını belirtmiştir. ${ }^{34}$

Üniversite öğrencilerinde yeme bozukluğunun \% 8-17 arasında değişen bir yaygınlığa sahip olduğu gösterilmekte ${ }^{13}$ ve batı ülkelerinde Asya ülkelerinden daha yaygın görüldüğü bildirilmektedir. ${ }^{35} \mathrm{Bu}$ çalışmada YTT-40 puan ortalamasının $(16,9 \pm 9,4)$ ölçekten alınabilecek en düşük ve en yüksek puanlar göz önünde bulundurulduğunda düşük düzeyde olduğu saptanmış ve olası yeme bozukluğu yaygınlığının ise \% 8,5 olduğu bulunmuştur. Fransa'da 3457 öğrenci ile yapılan bir çalışmada ${ }^{13}$ yeme bozukluğu yaygınlığ1 $\% 20,5, \quad$ Malezya'da $^{16}$ ve Türkiye'de $^{36} \quad \mathrm{k} 1 \mathrm{z}$ öğrencilerle yapılan çalışmalarda \%6,3 olarak rapor edilmektedir. 
Ülkemizde 2907 ergen ile yapılan başka bir çalışmada ${ }^{14}$ yeme bozukluğu nokta yaygınlığ $\% 2,3$, kadınlarda \%4,3; ayrıca ülkemizde YTT-40 kullanılarak 18-44 yaş aralığında 1122 bireyle yapılan bir çalışmada olası yeme bozukluğu yaygınlığı \%5,3, DSM-IV Eksen-I Bozuklukları İçin Yapılandırılmış Klinik Görüşme Formu (SCID-I) ile belirlenen nokta yaygınlığ1 ise \%1,5 olarak belirlenmiştir. ${ }^{37}$ Üniversite öğrencileri ile yapılan diğer çalışmalarda ise sırası ile $\% 4,2, \% 6,8, \% 8,8$, $\% 14$ olarak bildirilmiştir. ${ }^{38-41} \mathrm{Bu}$ çalışma ve bildirilen çalışmaların farklı sonuçlarında depresyon yalnızlık ve yeme bozukluğu yaygınlığının bireysel, coğrafik, toplumsal, kültürel, ekonomik ve zaman gibi faktörlerin etkili olabileceği söylenebilir.

$\mathrm{Bu}$ araştırmada öğrencilerin cinsiyeti ile BDE puan ortalaması arasında anlamlı bir fark olmadığı, erkek öğrencilerin UCLA-YÖ puan ortalamasının kızlara göre, kızların YTT-40 puan ortalamasının ise erkeklere göre anlamlı düzeyde yüksek olduğu belirlenmiştir. Benzer şekilde, bir çalışmada da cinsiyetin depresyonda anlamlı bir fark oluşturmadiğ $1,{ }^{26}$ diğer çalışmalarda kız öğrencilerin depresyon düzeyinin daha yüksek olduğu rapor edilmiştir. $^{7,29}$ Son yıllarda yapılan araştırmaların verilerine göre depresyon görülme riskinde kadın erkek arasındaki farkın giderek azaldığ 1 ve bu durumun gelişmiş toplumlarda kadının sosyoekonomik konumundaki değişmeye bağlı olabileceği gösterilmektedir. ${ }^{4}$ Bazı çalışmalarda ${ }^{12,30-32,42}$ erkeklerin, bazı çalışmalarda ${ }^{33,43}$ ise kızların daha yalnız olduğu ve diğer bazı çalışmalarda ise cinsiyetin yalnızlığı etkilemediği saptanmıştır. ${ }^{44,45}$ Kadınların daha yalnız olduğu, ancak yalnızlık durumunda erkeklerin kadınlara göre daha kırılgan oldukları da belirtilmektedir. $^{46} \mathrm{Bu}$ çalışmada erkek öğrencilerin kendilerini daha yalnız algılaması, öğrencilerin sosyal ilişkilerinin yeterli olmadığı ve iyi arkadaşlık ilişkileri geliştiremediği ile açıklanabilir. Mevcut çalışmanın sonucu ile benzer olarak yeme bozukluğu yaygınlığını değerlendiren çalışmalarda da yeme bozukluğunun kızlarda daha yüksek olduğu bulunmuştur. ${ }^{13,38,41,47}$ Yeme bozukluklarının kadınlarda görülme oranı erkeklerin on katı olup, olguların çoğunluğu 22 yaşından önce başlamaktadır. ${ }^{4}$ Bireyin kendi fiziksel görünüşünü algılaması olan beden imgesi kadınlar için anlamlı bir ruhsal olgudur. Beden memnuniyetsizliği ya da beden imajını kabul edememe bütün kilo sınıflandırmalarında kadınlarda daha fazla bildirilmiş ve beden memnuniyetsizliğinin yeme bozukluklarının gelişimini tetikleyebileceği ileri sürülmüştür. ${ }^{16}$ Mevcut çalışmanın sonucu literatüre uyumlu olup; kızlarda olası yeme bozukluğunun daha fazla olması; kızlarda beden ağırlığını yanlış algılama ve beden imgesi memnuniyetsizliği ile açıklanabilir.

Öğrencilerin öğrenim gördükleri fakülte/yüksekokul/meslek yüksekokula göre BDE puan ortalamaları arasındaki fark istatistiksel olarak anlamlı bulunmasına rağmen $(p<0,01)$, yapılan ileri analizde farkın anlamlı olmadığı, tüm bölümlerin benzer puan ortalamalarına sahip oldukları belirlenmiştir. Yapılan bir çalışmada ise tıp ve fen bilimleri alanında öğrenim gören öğrencilerde depresyonun anlamlı düzeyde daha yüksek olduğu rapor edilmiştir. ${ }^{7}$

Öğrencilerin fakülte/yüksekokul/meslek yüksekokula göre UCLA-YÖ puan ortalamasının istatistiksel olarak anlamlı olduğu saptanmıştır. Turizm ve Otelcilik Meslek Yüksekokulu ile İktisadi ve İdari Bilimler Fakültesi öğrencilerinin yalnızlık puanının diğer fakülte/yüksekokul/meslek yüksekokula göre daha fazla, Sağlık Yüksekokulu öğrencilerinin yalnızlık puanının ise diğer bütün fakülte/yüksekokul/meslek yüksekokula göre daha düşük olduğu görülmüştür. Yapılan çalışmalarda ise UCLAYÖ puan ortalamasının bölümlere göre farklılaşmadığı bildirilmiştir. ${ }^{30,45}$ Temel hemşirelik eğitiminde öğrencilerin profesyonel kimlik gelişimi için mesleğin belirli özellikleri ve standartlarını özümsemesi yanı sıra, kendini tanıma ve iletişim becerileri, problem çözme, stresle başetme, duygusal zeka, eleştirel düşünme gibi becerilere sahip olması ve uygulamalarına yansitması hedeflenmektedir. Mevcut çalışma sonucunda Sağlık Yüksekokulu (hemşirelik bölümü) öğrencilerinin yalnızlık puan ortalamasının düşük olması, belirtilen konuların müfredat içeriğinde yer alması ile birlikte bireysel, coğrafik, kültürel, toplumsal ve ekonomik yap1, ayrıca eğitim fakültesi ile diğer fakülte/yüksekokul öğrenci sayıları arasındaki farktan kaynaklanabileceği ile açıklanabilir. Öğrenim görülen fakülte/yüksekokul/meslek yüksekokul ile YTT-40 puan ortalaması arasında ise anlamlı düzeyde fark olmadığı tespit edilmiştir. Yapılan çalışmalarda da öğrenim görülen bölümlere göre yeme bozukluğu yaygınlığının fark oluşturmadığ belirtilmiștir. $^{13,40}$

Öğrencilerin sınıf düzeyi ile BDE puan ortalaması arasında istatistiksel olarak anlamlı fark olup, 1. sınıf öğrencilerinin BDE puan 
ortalamasının en yüksek olduğu ve yapılan ileri analizde 1. sinifların hem 2. siniflar, hem de 4. sınıflar ile fark oluşturduğu saptanmıştır. Sınıf düzeyi ile UCLA-YÖ ve YTT-40 puan ortalaması arasında ise anlamlı bir fark olmadığı belirlenmiştir. Yapılan bir çalışmada 4. sınıf öğrencilerinin 1. sinıf öğrencilerine göre BDE puan ortalamasının ${ }^{29}$, Hindistan'da tıp öğrencileri ile yapılan çalışmada 7. ve 9 . dönem öğrencilerinin depresyon düzeyinin 2., 4. ve 5. dönem öğrencilerine göre anlamlı düzeyde yüksek olduğu bildirilmiştir. ${ }^{27}$ Diğer çalışmalarda $^{31,32,40,45}$ da UCLA-YÖ puan ortalamasının sınıf düzeyine göre farklılaşmadığı, bir diğer çalışmada ise 1. sınıf öğrencilerinin UCLA-YÖ puan ortalamasının diğer sınıflara göre anlamlı düzeyde yüksek olduğu bildirilmiştir. ${ }^{12} \mathrm{Bu}$ çalışma sonucunda 1. sınıf öğrencilerinin üniversite eğitimine ve yeni bir çevreye uyum sürecinde daha fazla zorlanma yaşadıkları ve bu durumun depresyon belirtileri göstermelerine yol açtığ ayrica bireysel, toplumsal, kültürel ve ekonomik etkenlerin rolü olabileceği düşünülebilir.

Öğrencilerin sigara içme durumu ile BDE ve YTT-40 puan ortalaması arasında anlamlı bir fark olmadiğ 1 belirlenmiştir. Sigara içen öğrencilerin UCLA-YÖ puan ortalamasının ise sigara içmeyenlere göre anlamlı düzeyde yüksek olduğu tespit edilmiştir. Hindistan'da yapılan bir çalışmada sigara içmeyen öğrencilerin depresyon düzeyinin anlamlı olarak yüksek olduğ ${ }^{27}$, başka bir çalışmada ${ }^{30}$ öğrencilerin sigara içme durumunun UCLAYÖ, diğer bir çalışmada YTT-40 puan ortalamasını etkilemediğ ${ }^{41}$, diğer bir çalışmada ise yeme bozukluğu ile pozitif yönde ilişkili olduğu gösterilmiştir. ${ }^{13} \mathrm{Bu}$ çalışma sonucu yalnızlıkla başa çıkmak içen öğrencilerin sigara içme gibi etkisiz davranışsal başa çıkma yöntemi kullandığı, sigara içmeyen öğrenci sayısının fazla olduğu $(\% 78,4)$, yanı sira bireysel, toplumsal ve kültürel faktörlerin etkisi ile açıklanabilir.

Araştırmada öğrencilerin BKİ ile BDE ve YTT-40 puan ortalaması arasında anlamlı bir fark olmadığı; BKİ ile UCLA-YÖ puan ortalaması arasında ise anlamlı bir fark olduğu görülmüsstür. Yapılan ileri analizde obezlerin UCLA-YÖ puan ortalamasının zayıf, normal ve fazla kilolulardan daha yüksek olduğu belirlenmiştir. Amerika'da 4687 birinci sınıf tıp öğrencisi ile yapılan bir çalışmada da zayıf/normal kilolu olanlara göre fazla kilolu/obez öğrencilerin anlamlı düzeyde genel iyilik durumlarının ve beden algılarının daha kötü ve daha yalnız olduğu bildirilmektedir.
Ayrıca algılanan ve içselleştirilmiş kilo damgalanmasının fazla kilolu/obez öğrencilerde iyi oluşu kötüleştirebileceği rapor edilmektedir. ${ }^{48}$ Yurt dışında yapılan başka bir çalışmada BKİ ve beden memnuniyetsizliğinin kilo kontrolü ve gıda tüketimi ile ilişkili kaygıda artışa neden olduğu da belirtilmektedir. ${ }^{49}$ Bir çalışmada BKİ'si yüksek öğrencilerin $^{36}$ diğer bir çalışmada zayıf ve şişman olan öğrencilerin yeme bozuklukları açısından risk altında oldukları bulunmuştur. ${ }^{40}$ Bir çalışmada ise normal kilolu öğrencilerin olası yeme bozukluğunun anlamlı düzeyde yüksek olduğu bildirilmiştir. ${ }^{41}$ Başka bir çalışmada da aşırı kilolu/obez olan, beden ağırlığından memnun olmayan, diyet yapan ve stres durumunda beslenmesinin etkileneceğini belirten öğrencilerin yeme bozuklukları açısından riskli bulunduğu gösterilmektedir. ${ }^{47}$ Mevcut çalışma sonucunda normal kiloda olan öğrencilerin çoğunlukta (\%77) olmasının yanı sıra bireysel, coğrafik, kültürel, toplumsal ve ekonomik yapının etkili olabileceği söylenebilir.

$\mathrm{Bu}$ çalışmada öğrencilerin yaşı ile BDE, UCLA-YÖ ve YTT-40 puan ortalamaları arasında anlamlı bir ilişki olmadığı tespit edilmiştir. Yapılan çalışmalarda da yaşın yalnızlik durumunu ${ }^{43,45}$ ve yeme bozukluğunu $^{40,41}$ etkilemediği, başka bir çalışmada ise yaşı büyük öğrencilerin yeme bozukluğu yaygınlığının $(\% 17,6)$ daha yüksek olduğu bulunmuştur. ${ }^{47}$ Diğer çalışmalarda yaşı büyük olan öğrencilerin daha yalnız ${ }^{31,33}$ ve yaşı küçük olan öğrencilerin yaşı daha büyük olanlara göre depresyon düzeyinin anlaml olarak yüksek olduğu bildirilmiştir. ${ }^{27,29}$ Mevcut çalışmanın sonucuna göre bireysel, ruhsal, toplumsal ve kültürel etkenlerin öngörücü olabileceği düşünülebilir.

Bu çalışmada BDE ile UCLA-YÖ arasında çok zayıf, YTT-40 arasında zayıf düzeyde pozitif yönlü anlamlı bir ilişki belirlenmiş, UCLA-YÖ ile YTT-40 arasında ise anlamlı bir ilişki bulunmamıştır. Yalnızlık bireyin arzu edilen ve mevcut olan toplumsal ve duygusal ilişkilerinin nitelik ve niceliği arasındaki uyuşmazlık durumunda ortaya çıkan karmaşık ruhsal toplumsal bir yapidır. Kuramsal olarak toplumsal yapıdaki öznel eksiklik toplumsal yalnızlık, yalnız olmanın öznel deneyimi ise duygusal yalnızlık olarak incelenmekte ve sosyal ve duygusal yalnızlığın fiziksel ve ruhsal sağlığı olumsuz etkilediği bildirilmektedir. $^{34} \quad$ Yeme bozukluğunda depresyon başta olmak üzere eş tanılar yaygın görülmekte olup ${ }^{37}$ depresyon ve yeme bozukluğu arasındaki ilişki karşılıklı ve iki 
yönlüdür. Depresyon yeme bozukluğu patolojisinin ilerlemesine yol açmakta, doğru olmayan diyet ve beslenme ise depresyon gelişmesinde anlamlı rol oynayan kimyasal dengesizliğe neden olabilmektedir. ${ }^{16}$ Yurt dışında $^{13,16}$ ve ülkemizde $^{14,37}$ üniversite öğrencileri ile yapılan çalışmalarda da BDE ile YTT-40 puanları arasında pozitif yönlü anlamlı düzeyde bir ilişki belirlenmiştir. Bir çalışmada da yeme bozukluklarında en sık konulan eş tanının majör depresif bozukluk olduğu belirlenmiştir. ${ }^{37}$ Ayrıca yurt dışında ergenlerle yapılan bir çalışmada etkisizlik ve etkileşimsel farkındalık gibi ruhsal özelliklerin gelişimini ortaya çıkaran depresyon, obsesiflik ve benlik saygısının, yeme bozukluğu risk sürecinde belirleyici etkenler olduğu bildirilmektedir. ${ }^{49}$ Diğer çalışmalarda da yalnızlık ve depresyon arasında pozitif yönlü bir ilişki ${ }^{12,34,50}$ ve başka bir çalışmada yalnızlık ve ruhsal bozukluk düzeyi yüksek öğrencilerin stresle etkili başa çıkma yöntemleri kullanamadığ 1 belirlenmiştir. ${ }^{10}$ Mevcut çalışmanın sonucu literatüre uyumlu olup, depresyonun yalnızlık ve yeme bozukluğu ile ilişkili olduğunu göstermiştir. Yeme bozukluğunda bireysel, ruhsal, toplumsal ve kültürel etkenlerin öngördürücü olduğu ${ }^{16}$, duygusal yeme davranışlarının, olumsuz duygular ya da zorlanmadan kurtulmak için baş etme yöntemi olarak kullanıldığı bildirilmektedir. $^{51} \quad$ Birleşik Arap Emirlikleri'nde gençlerle yapılan bir çalışmada da tıkanırcasına yeme bozukluğunun yalnızlık ve sıkıntı gibi olumsuz duyguları hafifleterek uygunsuz başa çıkma stratejisi olarak işlev görebileceği belirtilmektedir. ${ }^{52} \mathrm{Bu}$ çalışmada yalnızlık ile yeme bozukluğu arasında anlamlı bir ilişki olmaması, öğrencilerin yalnızlıkla başa çıkmada bozulmuş yeme davranışı gibi etkisiz bir başa çıkma yöntemi kullanmadığını ve çalışma sonucunda başka faktörlerin etkili olabileceğini düşündürmektedir.

\section{SONUÇ}

$\mathrm{Bu}$ çalışmada öğrencilerin orta düzeyde yalnızlık yaşadığı, \%32,8'inin depresif bozukluk yönünden risk altında olduğu, $\% 8,5$ 'inin olası yeme bozukluğu gösterdiği ve yalnızlık algısının depresyon riskinde, depresyonun ise olası yeme bozukluğunda belirleyici olduğu tespit edilmiştir. Ayrıca cinsiyetin depresif belirti riskini etkilemediği, erkeklerin daha yalnız ve kızların olası yeme bozukluğu puan ortalamasının daha yüksek olduğu saptanmıştır. Bu nedenle bu çalışmanın sonuçları öğrencilerde ruhsal girişim programlarının gerekliliğini göstermektedir. Üniversitelerin psikolojik danışma ve rehberlik merkezlerinde sistematik bir şekilde kolay ve hızlı tarama testleri ile depresyon, yalnızlık ve yeme bozukluğu gibi ruhsal bozuklukların erken tanı ve tedavisine yönelik çeşitli psikoterapi yaklaşımları ve ruhsal eğitim programları ile bu bozuklukların doğası, olası sonuçları, kendini tanıma, etkili iletişim, problem çözme ve stresle başa çıkma becerileri, atılgan davranış özellikleri ve yaşam amaçları belirleme konularında rehberlik ve danışmanlık yapılmalıdır. Ulaşılabilir, karşılanabilir ve kabul edilebilir hizmetler ile gençlerin, kendi sağlıklarını koruma bilincine erişmesi ve kendi yaşamlarını etkileyecek her türlü çalışmanın planlanması, uygulanması ve değerlendirilmesi aşamalarına aktif olarak katılmaları sağlanmalıdır.

\section{Çalışmanın Sınırlılığı ve Genellenebilirliği}

Bu çalışmanın sınırlılığı, kesitsel nitelikte bir çalışma olmasından dolayı neden-sonuç çıkarımında sağlıklı sonuçların elde edilememesidir. Çalışmanın sonuçları Erzincan il merkezinde öğrenim gören öğrencileri temsil edebilir nitelikte olmasına rağmen, farklı şehirlerdeki üniversite öğrencilerine ve öğrenci olmayan gençlere genellenemez.

\section{KAYNAKLAR}

1. Pekcan H. Adolesan Sağlığı. Güler Ç, Akın L. Editörler. Halk Sağlığı Temel Bilgiler 1. 3. Bask1. Hacettepe Üniversitesi Yayınları Tıpkı Basım 2015. s. 486-538.

2. Blotnicky KA, Mann LL, Joy PR. An assessment of university students' healthy eating behaviors with the expectancy theory. ASBBS eJournal 2015;11: 31.

3. Musiat P, Conrod P, Treasure J, Tylee A, Williams C, Schmidt U. Targeted prevention of common mental health disorders in university students: randomised controlled trial of a transdiagnostic trait-focused web-based intervention. PLoS One 2014; 9: e93621.

4. Öztürk MO, Uluşahin A. Ruh Sağlığı ve Bozuklukları. 14. Baskı. Miki Matbaacilık, Nobel Tip Kitabevleri, Ankara 2016. s: 273, 465-474.

5. Şenol S, İşeri E, Şener Ş. Ruhsal Hastalıklar. Yüksel N. Editör. 3. Baskı. MN Medikal \& Nobel Basım Yayın Ticaret ve Sanayi Ltd. Şti. Ankara 2006. s. 531-537.

6. Eskin M, Ertekin K, Harlak H, Dereboy Ç. Lise öğrencisi ergenlerde depresyonun yaygınlığ1 ve ilişkili olduğu etmenler. Türk Psikiyatri Dergisi 2008;19:382-389. 
7. Amr M, Amin TT, Saddichha S, Malki SA, Samail MA, Qahtani NA, et al. Depression and anxiety among Saudi University students: prevalence and correlates. The Arab Journal of Psychiatry 2013; 24:1-7.

8. Lotfi MH, Aminian AH, Ghomizadea A, Zarea S. Prevalence of depression amongst students of Shaheed Sadoughi University of Medical Sciences, Yazd, Iran. Iranian Journal of Psychiatry and Behavioral Sciences 2010;2:51-55.

9. Çelikel FÇ, Erkorkmaz Ü. Üniversite öğrencilerinde depresif belirtiler ve umutsuzluk düzeyleri ile ilişkili etmenler. Arch Neuropsychiatry 2008;45:122-129.

10. Demirüstü C, Binboğa $D$, Öner $S$, Özdamar K. The relationship between the ways of coping with Stress Inventory and the General Health Questionnaire-12 scores among university students. Turkiye Klinikleri J Med Sci 2009;29:70-6.

11. Öz F. Sağlık Alanında Temel Kavramlar. Yenilenmiş 2. Baskı. Mattek Matbaacılık Bas. Yay. Tic. Ltd. Şti. Ankara 2010. s. 151-161.

12. Ceyhan E, Ceyhan AA. Üniversite psikolojik danışma merkezine başvuran öğrencilerin yalnızlık ve depresyon düzeyleri. Eğitim ve Bilim 2011;36: 6580.

13. Tavolacci MP, Grigioni S, Richard L, Meyrignac G, Dechelotte P, Ladner J. Eating disorders and associated health risks among university students. J Nutr Educ Behav 2015;47:412-420.

14. Vardar E, Erzengin M. Ergenlerde yeme bozukluklarının yaygınlığ 1 ve psikiyatrik eş tanıları iki aşamalı toplum merkezli bir çalışma. Türk Psikiyatri Dergisi 2011; 22:205-12.

15. Amerikan Psikiyatri Birliği, Ruhsal Bozuklukların Tanısal ve Sayımsal Elkitabı, Beşinci Baskı (DSM-5), Tanı Ölçütleri Başvuru Elkitabı. Çev. Köroğlu E, Hekimler Yayın Birliği, Ankara, 2014. s: 171-179.

16. Manaf NA, Saravanan C, Zuhrah B. The prevalence and inter-relationship of negative body image perception, depression and susceptibility to eating disorders among female medical undergraduate students. Journal of Clinical and Diagnostic Research 2016;10: 01-04.

17. WHO. Obesity: preventing and managing the global epidemic. World Health Organ Tech Rep Ser, Geneva. 2000;894:1-253.

18. Beck AT. An inventory for measuring depression. Arch Gen Psychiatry 1961; $4: 561-571$.
19. Hisli N. Beck Depresyon Envanterinin üniversite öğrencileri için geçerliği, güvenirliği. Psikoloji Dergisi 1989;7:3-13.

20. Aydemir Ö, Köroğlu E. Psikiyatride kullanılan klinik ölçekler. Ankara: Hekimler Yayın Birliği; 2007. s:121, 325.

21. Russell D, Peplau LA, Cutrona C E. The revised UCLA Loneliness Scale: Concurrent and discriminant validity evidence. J Pers Soc Psychol 1980; 39: $472-480$

22. Demir A. UCLA Yalnızlık Ölçeğinin geçerlik ve güvenirliği. Psikoloji Dergisi 1989;7:14-18.

23. Garner DM, Garfinkel PE. The Eating Attitudes Test: an index of the symptoms of anorexia nervosa. Psychol Med. 1979; 9:273-279.

24. Erol N, Savaşır I. Yeme tutum testi: anoreksiya nervosa belirtiler indeksi. Psikoloji Dergisi 1989; 7:19-25.

25. Öner N.Türkiye'de Kullanılan Psikolojik Testler. 3. Baskı. Boğaziçi Üniversitesi Yayınları, İstanbul 1997. s: 596.

26. Peltzer K, Pengpid S, Olowu S, Olasupo M. Depression and associated factors among university students in Western Nigeria. Journal of Psychology in Africa 2013;23:459-466.

27. Iqbal S, Gupta S, Venkatarao E. Stress, anxiety \& depression among medical undergraduate students \& their sociodemographic correlates. Indian J Med Res 2015; 141: 354-357.

28. Deveci SE, Ulutaşdemir N, Açık Y. Bir sağlık yüksekokulunda öğrencilerde depresyon belirtilerinin görülme sıklığı ve etkileyen faktörler. Firat Tip Derg 2013;18: 98-102.

29. Softa HK, Kaya S. Sağlık yüksekokulu öğrencilerinin depresyon düzeylerini etkileyen faktörlerin incelenmesi. Gümüşhane Üniversitesi Sağlık Bilimleri Dergisi 2013; 2: 214-229.

30. Karaoğlu N, Avşaroğlu S, Deniz ME. Yalnız mısın? Selçuk Üniversitesi öğrencilerinde yalnızlık düzeyi ile ilgili bir çalışma. Marmara Medical Journal 2009;22:19-26.

31. Kaya N, Kaya H, Atar NY, Turan N, Eskimez Z, Palloş A, ve ark. Hemşirelik ve ebelik öğrencilerinin öfke ve yalnızlık özellikleri. Hemşirelikte Eğitim ve Araştırma Dergisi 2012;9:18-26.

32. Yilmaz E, Yilmaz E, Karaca F. Üniversite öğrencilerinin sosyal destek ve yalnızlık düzeylerinin incelenmesi. Genel Tip Derg 2008;18:71-79.

33. Seçim ÖY, Alpar Ö, Algür S. Üniversite ögrencilerinde yalnızlık: Akdeniz 
Üniversitesinde yapılan ampirik bir araştırma. Elektronik Sosyal Bilimler Dergisi 2014;13:200-215.

34. Hayley AC, Downey LA, Stough C, Sivertsen B, Knapstad M, Overland S. Social and emotional loneliness and selfreported difficulty initiating and maintaining sleep (DIMS) in a sample of Norwegian university students. Scand J Psychol 2017;58:91-99.

35. Qian J, Hu Q, Wan Y, L1 T, Wu M, Ren $Z$, et al. Prevalence of eating disorders in the general population: a systematic review. Shanghai Archives of Psychiatry 2013; 25:213-222.

36. Çelik S, Yoldaşcan EB, Okyay RA, Özenli Y. Kadın üniversite öğrencilerinde yeme bozukluğunun yaygınlığı ve etkileyen etkenler. Anatolian Journal of Psychiatry 2016; 17:42-50.

37. Semiz M, Kavakcı Ö, Yağız A, Yontar G, Kugu N. Sivas il merkezinde yeme bozukluklarının yaygınlığı ve eşlik eden psikiyatrik tanılar. Türk Psikiyatri Dergisi 2013; 24:149-57.

38. Ulaş B, Uncu F, Üner S. Sağllk yüksekokulu öğrencilerinde olası yeme bozukluğu sıklığ1 ve etkileyen faktörler. İnönü Üniversitesi Sağlı Bilimleri Dergisi 2013;2:15-22.

39. Tozun M, Ünsal A, Ayrancı U, Arslan G. Prevalence of disordered eating and its impact on quality of life among a group of college students in a province of west Turkey. Salud Publica Mex 2010; 52:190198.

40. Yilmaz D, Ayaz A, Demirel ZB. Kız üniversite öğrencilerinde yeme tutumunun kişisel beden imaj1 algısı ile ilişkisi. Beslenme ve Diyet Dergisi 2013;41:227233.

41. Ünalan D, Öztop DB, Elmalı F, Öztürk A, Konak D, Prrlak B, ve ark. Bir grup sağlık yüksekokulu öğrencisinin yeme tutumları ile sağlıklı yaşam biçimi davranışları arasındaki ilişki. İnönü Üniversitesi Tip Fakültesi Dergisi 2009;16:75-81.

42. Serin NB, Aydınoğlu N, Aysan F. Examining the predictors of loneliness levels of university students. Procedia Social and Behavioral Sciences 2010;2:704-708.

43. Bek H. An Analysis on loneliness level of Afghani university students in Turkey in respect of some variables. Mevlana International Journal of Education 2014;2:132-138.

44. İlhan T. Üniversite öğrencilerinde yalnızlık: cinsiyet rolleri ve bağlanma stillerinin yalnızlığı yordama güçleri.
Kuram ve Uygulamada Eğitim Bilimleri 2012;12:2377-2396.

45. Öztürk H, Sevindik FN, Yaman SÇ. Öğrencilerde yalnızlık ve sosyal destek ile bunlara etki eden faktörlerin incelenmesi. Firat Üniversitesi Sosyal Bilimler Dergisi 2006;16: 383-394.

46. Yaşar RM. Yalnızlık. Fırat Üniversitesi Sosyal Bilimler Dergisi 2007;17:237-260.

47. Kadıoğlu M, Ergün A. Üniversite öğrencilerinin yeme tutumu, öz-etkililik ve etkileyen faktörler. MÜSBED 2015;5:96-104.

48. Phelan SM, Burgess DJ, Puhl R, Dyrbye LN, Dovidio JF, Yeazel M, et al. The adverse effect of weight stigma on the well-being of medical students with overweight or obesity: findings from a national survey. J Gen Intern Med 2015;30:1251-8.

49. De Caro EF, Di Blas L. A prospective study on the reciprocal influence between personality and attitudes, behaviors, and psychological characteristics salient in eating disorders in a sample of nonclinical adolescents. Eat Disord 2016;24:453-68.

50. Daniel K. Loneliness and depression among university students in Kenya. Global Journal of Human Social Science Arts \& Humanities 2013;4:11-18.

51. Sevinçer GM, Konuk N. Emosyonel yeme. Journal of Mood Disorders 2013;3:171-8.

52. Schulte SJ. Predictors of binge eating in male and female youths in the United Arab Emirates. Appetite 2016;105:312-9. 